\title{
Drivers of Livelihoods Diversification in Rungwe District
}

\author{
Atupakisye S. Kalinga ${ }^{1}$, Richard Y. M. Kangalawe ${ }^{2} \&$ James G. Lyimo $^{2}$ \\ ${ }^{1}$ The Mwalimu Nyerere Memorial Academy, Dar es Salaam, Tanzania \\ ${ }^{2}$ University of Dar es Salaam, Dar es Salaam, Tanzania \\ Correspondence: Atupakisye S. Kalinga, The Mwalimu Nyerere Memorial Academy, P.o. BOX 9193, Dar es \\ Salaam, Tanzania. Tel: 255-7-8437-0266. E-mail:atusamka@yahoo.com
}

Received: May 1, 2019

doi:10.5539/jsd.v12n4p86
Accepted: June 22, 2019 Online Published: July 30, 2019

URL: https://doi.org/10.5539/jsd.v12n4p86

\begin{abstract}
This paper examined the factors influencing livelihoods diversification in Rungwe district. Specifically, the study assessed the livelihoods activities in the study area and determined the drivers of livelihoods diversification. The study was carried out in six villages of Rungwe District, Mbeya Region in which about 253 households were interviewed for the study. Data was collected through documentary review, household interviews, focused group discussions (FGDs), key informant interviews (KIIs), transect walks and field observation. Quantitative data were analysed using SPSS version 20 and Excel spreadsheet. While chi-square test was conducted to determine the associations between influencing factors and livelihoods activities, content analysis was used to analyse qualitative data. The study results showed that there were various livelihoods activities in the study villages such as cash crop production, livestock keeping, trade and wage labour. Livelihoods diversification was influenced by factors like markets, climate, population, land shortages, institutions, policies, and livelihoods assets. However, agriculture has remained the main occupation of households in Rungwe District. Moreover, market appeared to be a strong factor in influencing livelihoods diversification in the area than any other factors. On that basis, this paper recommends that livelihoods activities which were environmentally friendly should be encouraged. Additionally, markets and transport services should be improved to provide equal opportunities for diversification among rural populations.
\end{abstract}

Keywords: crop diversification, livelihood, livelihoods diversification

\section{Introduction}

Livelihoods diversification has emerged as a key strategy for poverty alleviation among rural households in various parts of the world (Assan, 2014; Ellis, 2000). For instance, in Sub-Saharan Africa (SSA), there has been about 30-50 percent of households who have relied on non-farm income sources and may reach 80-90 percent of households in Southern Africa (Bryceson, 2000). In South Asia, about 60 percent of rural households' income comes from non-farm sources (Ellis, 2000).Various factors have compelled farmers to have a portfolio of activities instead of depending on only one type of livelihoods activity. This is due to the recognition that livelihoods diversification is necessary for improvement of food supply and household income (Mwakaje, 2008).

While various scholars have attempted to provide a wide literature on the role of livelihoods diversification on peoples wellbeing (Bryceson, 2004; Ellis, 2000; Ellis and Allison, 2004; Urrasa, 2010), yet there is a limited understanding on the reasons for adoption of multiple livelihoods activities. This calls for the need to understand the factors that influence livelihoods diversification in Rungwe district. This paper analyses the livelihoods activities and the factors that promote livelihoods diversification in Rungwe District. It studies the livelihoods activities and the factors that influence diversification of livelihoods in the district. Therefore, this paper responds to the following questions; in what ways does livelihoods diversification has occurred in Rungwe district; what factors have influenced livelihoods diversification in the study villages. The paper is expected to contribute to the body of knowledge on livelihoods diversification and on factors influencing livelihoods diversification and recommends on the appropriate strategies for policy options towards enhancing the attainment of sustainable livelihoods. The rest of the paper is organized into the following sections. In the second section, the paper presents the literature review whereas the third section describes the methodology used for the study. While the fourth presents the results and discussions, the last part provides an analysis of the major findings for the paper alongside with the conclusions and recommendations in response to challenges identified 
in the study.

\section{Literature Review}

\subsection{Theoretical Framework}

The conceptual context of the study is supported by the Capability Approach developed by Sen (2005) and Nussbaum (2000) which mainly assesses human well-being in the context of sustainable livelihood framework (SLF). Basically, the model is about the ability of people to have freedom for performing activities that bring happiness and satisfaction to their lives. The core concept of this approach is achievement, which relates to living conditions and capability which also relates to freedom in the constructive manner (Robeyns, 2003). With reference to the Capability Approach, this study is based on the notion that livelihoods diversification can improve or retard community development. This study has used the capability approach in the context of the sustainable livelihood framework (SLF) which best explains the linkages between livelihoods diversification and poverty at household level.

The SLF show that households possess different levels of resource endowment and capabilities with different scales of exposure to institutions and policies that condition the environment in which they operate, and the interaction of these factors determine their livelihoods choices and the consequent differences in welfare outcomes. Therefore, in the different applications of the SLF, significant emphasis has been put on the core issue of individual and household endowments in which various groups and individuals construct and identify possible livelihoods strategies that would bring about optimal returns such as increased income and well-being, reduced vulnerability natural disaster, improved food security and sustained use of available resources. Decisions on livelihoods choices are not independent of the institutional processes and structures that dictate the order of economic interactions (Katega and Lifuliro, 2014).

\subsection{Empirical Literature Review}

Livelihoods diversification can be referred to as the practice of adopting various livelihoods activities in an economy (Ashley, Start and Slater, 2003). Livelihoods diversification can refer to an increasing a range of activities (regardless of the sector), or a move away from traditional rural activities like agriculture to non-traditional ones (Start and Crag, 2004). Livelihoods diversification can be considered as a combination of activities carried out by households to achieve their livelihoods goals (Ellis and Allison, 2004). Also, livelihoods diversification has been defined as income strategies of rural populations to increase the number of their livelihoods activities, regardless of the location or sector (Loison and Loison, 2016).

African farmers diversify their livelihoods through on-farm and off-farm activities (Iiyama, Kariuki, Kristjanson, Kaitibie and Maitima, 2008). In rural areas livelihoods diversification has generally occurred due to an increased role of off-farm activities among many farming households in SSA (Waren, 2002). In Ethiopia, farming households have generated a considerable income from combined livelihoods activities like the combination of crops, tree plantation, sheep fattening and poultry activities (Assan and Beyene, 2013). A study from Kerio Valley, in Kenya indicated that households have involved in a variety of activities such as casual off-farm activities, traditional livestock, staple crops and fruits production so as to improve their income and food security (Iiyama et al., 2008).

In Ethiopia, there are a number of skilled craftsmen like male carpenters and mechanics, while females have traded in millet beer, prepared food and carried out petty trade in cereals, butter, groundnut oil and processed grains (Tefera, Perret and Kirsten, 2004). In East Africa livelihoods diversification has emerged as a coping and risk mitigation strategy among pastoral societies (Little, Smith, Cellarius, Coppock and Barrett., 2002). This helps herders to generate income from other income sources rather than depending on the sale of livestock or livestock products. Some livestock keepers migrated to cities for wage employment so as to improve their livelihoods (McCabe, 2003).

In Tanzania, livelihoods diversification has been associated with a shift from growing traditional food crops to producing higher-value perishable crops (Lesslie, 2004). A study by Larsson (2001) in Meru areas in Tanzania, reported that some farmers have diversified from agriculture into building houses for business because land has become more important for building on than for agriculture. A study by Kwai and Hilson (2010) in Morogoro and Mbeya regions showed that livelihoods diversification from agriculture into mining has provided employment and income for rural households in response to a deteriorating agricultural sector.

Besides farming, some people in Rungwe District have engaged in activities like weaving, shoe repairs, hair salons, pulling carts, butcher shops, kiosks/tea rooms, midwifery, bicycle repairs, electronics and traditional healing to improve their standards of living (Mwamfupe, 1998). Also, dairy farming has become one of the 
important income generating activities that play a key role in the lives of rural people (Mwakaje, 2008). Dairy farming was facilitated by an increasing demand for milk products, both fresh milk and butter, especially in urban centres. Consequently, households have diversified from raising beef cattle into dairy farming in order to meet the demand for milk, especially in urban markets.

Livelihoods diversification has occurred due to various factors. For instance, in many African countries climate variability is recognized as one of the main drivers of diversification in the area. Households have engaged in activities that are less susceptible to disruption from climate impacts (Newsham and Thomas, 2009). Woodfine (2009) revealed that in SSA farmers have become selective in terms of what crop varieties to grow due to changing weather patterns. For instance, they have selected to grow crop types that are resistant to climatic conditions such as floods and drought.

Climate change and extreme weather events like floods and drought may push farming households into growing drought-resistant and fast-maturing crops (Low, 2005; Devereux, Teshome and Sabates-Wheeler, 2005) which may necessitate diversification from traditional crops into new crop varieties. The study by Yenesew, Okoyo and Beyene, (2015) in Ethiopia indicated that without livelihoods diversification into non-farm activities, agricultural productivity alone will not be successful in improving livelihoods of the rural population. Kangalawe, Liwenga, Kabumbuli and Walingo (2008) pointed out that many rural households diversify their livelihoods activities instead of depending only on agriculture to reduce risk that may occur, especially during the dry season, thus emphasised on growing drought-resistant crops. A study by McCabe (2003) reported that in recent years pastoralists have diversified into trade and crop cultivation due to climate change impacts and cattle diseases.

Access to market and market forces has influenced livelihoods diversification (Readon, 1997). With better access to the market, farmers are encouraged to diversify into production of higher-value crops or livestock products, but the long distance to the market may reduce their opportunities to diversify (Lesslie, 2004). Inadequate access to good markets for agricultural produce compelled local communities around Lake Victoria to seek alternative livelihoods, such as industries, fishing, livestock keeping and grass farming (Kangalawe et al., 2008). Also, in Rukwa Region poor markets for agricultural produce forced communities to seek alternative income sources (Urassa, 2010). The influence of market is associated with access to good infrastructure such as roads, which are very important for transporting produce and promoting livelihoods diversification in the area through linking local communities to markets (Sserunkuuma, Pender and Nkonya 2001). A study in Uganda by Nkonya, Pender, Jagger, Sserunkuuma, Kaizzi and Ssaliu (2004) noted that in areas with a good market, farmers prefer to produce high-value crops such as horticultural crops so as to maximise their income.

Other factors such as population increase have also resulted in livelihoods diversification in the Lake Victoria basin (Kangalawe et al. 2008). The increase in population density caused by internal growth and in-migration, the land available per capita has decreased (Kangalawe et al., 2008). This has forced people to look for other sources of income, such as trade and building houses for business (Larsson, 2001). Geist and Lambin (2002) pointed out that increasing population may lead to a shortage of land thus compelling rural farming households to diversify into non-farm activities in order to fulfill household needs.

Dercon and Krishnan (1996) argued that the ability of households to adopt more profitable livelihoods depend on their access to assets that are needed to pursue different livelihoods activities, such as access to capital and credit, skills and land or livestock. Constraints were felt most by poor rural households, the landless, those with little access to credit and those without assets; particularly land (Reardon, 1997). The study by Yenesew et al. (2015) found that the shortage of land has made it difficult to continue depending on agriculture as a primary source of income where the majority of households cultivate less than 0.5 ha, which cannot meet the requirements of households. Pender, Jagger, Nkonya and Sserunkuuma (2004) reported that due to extreme land scarcity in the densely populated areas of Uganda, crop diversification led to reduced fallowing whereas fallowing for a year or more is no longer practiced in the area.

Available literature point out further that formal and informal institutions help to structure livelihoods diversification through developing laws or by-laws, which may specify who can diversify and the potential rewards from diversification. For instance, households' decisions may be affected by rules on land use set by the government and/or the community (Davies, 1996). Poor access to education may prevent some households from diversifying. Without access to resources, households are less likely to have diversified activities, and thus continue to be dependent on the land (Barrett, Reardon and Webb 2001).

\section{Methodology}

In this paper, the data which have been used are based on the study that was conducted in six villages which are Kikota, Ilolo, Idweli, Ntokela, Masukulu and Ijigha in Rungwe District, Mbeya Region. The target populations 
for this study were the household heads in the selected villages. Rungwe Mountain has a favourable climate for agriculture, which has attracted many people to be involved in a diversity of activities in order to improve their wellbeing (Majule, 2010). The methods of data collection comprised of documentary review, household interviews, focused group discussion (FGDs), key informant interviews (KIIs), transect walks and field observation. Secondary data were mainly obtained through documentary review in which various documents were reviewed to obtain secondary data from various publications. These included books, journals, official government reports and other published and unpublished materials from various sources relevant to the study subject, including the internet. With respect to data analysis, quantitative data were analysed by using SPSS version 20 and Excel spreadsheet while content analysis was used to analyse qualitative data. The findings were presented in various ways, including tables and graphs.

\section{Results and Discussion}

\subsection{Livelihoods Activities in Rungwe District}

The study findings indicated that many households have diversified their livelihoods into several activities. In almost all the study villages all households indicated that they have involved in food crop production. In addition to food crop production, the majority of respondents have involved in cash crop production, livestock keeping and trade so as to improve their livelihoods (Figure 1).

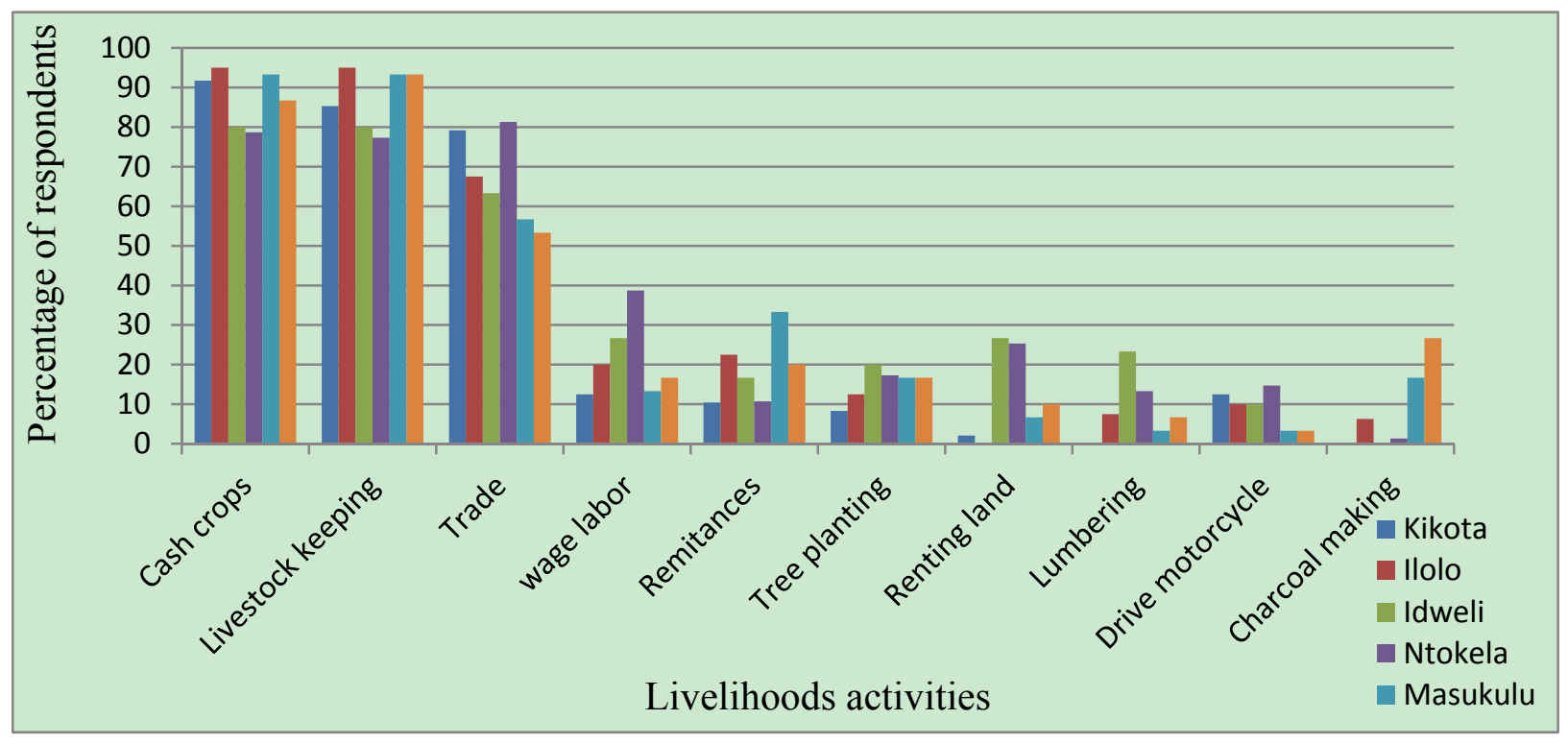

Figure 1. Households involvement in different livelihoods activities

As it can be observed from Figure 1, many farming households have diversified from food production to cash crop production (Figure 1). A high percentage of this was from Kikota and Ilolo villages because the moderate climate of the midland zone favoured the growing of different crops in the area. The supply of round potatoes was constant in Ntokela and Idweli villages because the cold climatic condition of the highland zone favours the production of the crop than other zones. Unlike other crops, maize and beans were observed to have constant supply throughout all the study villages because the climatic condition of the entire zone has favoured the crops in the area.

In this regard, crop diversification has been an important livelihoods activity whereby farmers have used a range of crops or adopted improved crop varieties such as of avocadoes, banana, maize, round potatoes and beans to improve their income and food security in the study villages. Households have produced banana, paddy, and round potatoes for sale than for consumption while traditionally have been producing cash crops like coffee, tea, cocoa and pyrethrum as their main sources of income.

The study revealed that many households (85.8\%) have diversified the farming system based on crop cultivation into livestock keeping such as cattle, goat, sheep, pig and chickens. The increasing demand for meat, milk and eggs in urban areas promoted diversification into livestock keeping in the study villages. Within livestock keeping, they have diversified into different categories, for instance, from subsistence to keeping livestock for sale, from local breeds to improved breeds as well as from traditional ways of livestock keeping to stall-feeding. 
Key informant interviews (KIIs) indicated that the growing demand for livestock products like meat, eggs, milk and milk products led to high involvement in livestock keeping. For instance, the roasted pig meat commonly known as kitimoto is greatly demanded in both rural and urban markets while the roasted beef and chicken meat were highly demanded to be consumed with banana and round potatoes. About $58.5 \%$ of households indicated to have adopted improved dairy cattle in order to meet the demand for milk, especially in urban markets

The study revealed further that households were found to have diversified from crop cultivation into trade in which Kikota and Ilolo villages had a higher percentage of respondents due to the presence of a well-developed Kiwira market. Consequently, this encouraged traders from various wards and districts as well as other regions and other countries to conduct trade in the area. The involvement in trade has increased more in the 2000s while before 1990s very few farmers were involved in trade. It was observed that before 1990s females were much more involved in trade than males. However, since 1990s both males and females were participating in trade because before 1990s more males were involved in coffee production which had good market price while since 1990s its price declined, which created a need to seek other income sources. The FGDs and KIIs reported that in the 1990s traders conducted trade only within the country while from the 2000s traders started crossing the borders with some traders from countries like Malawi, Zambia, Dubai and South Africa have been coming to the district for trade. This indicates that trading activities in Rungwe district have entered the world market economy. For example, bananas and avocadoes are not only traded within the country but also with other countries such as those from Malawi, South Africa, Dubai and Zambia.

\subsection{Drivers of Livelihoods Diversification}

With respect to this aspect, the results revealed a number of factors that have influenced livelihoods diversification in which market; land shortages, climate and population were among the most important factors that have influenced livelihoods diversification in the study villages (Figure 2).

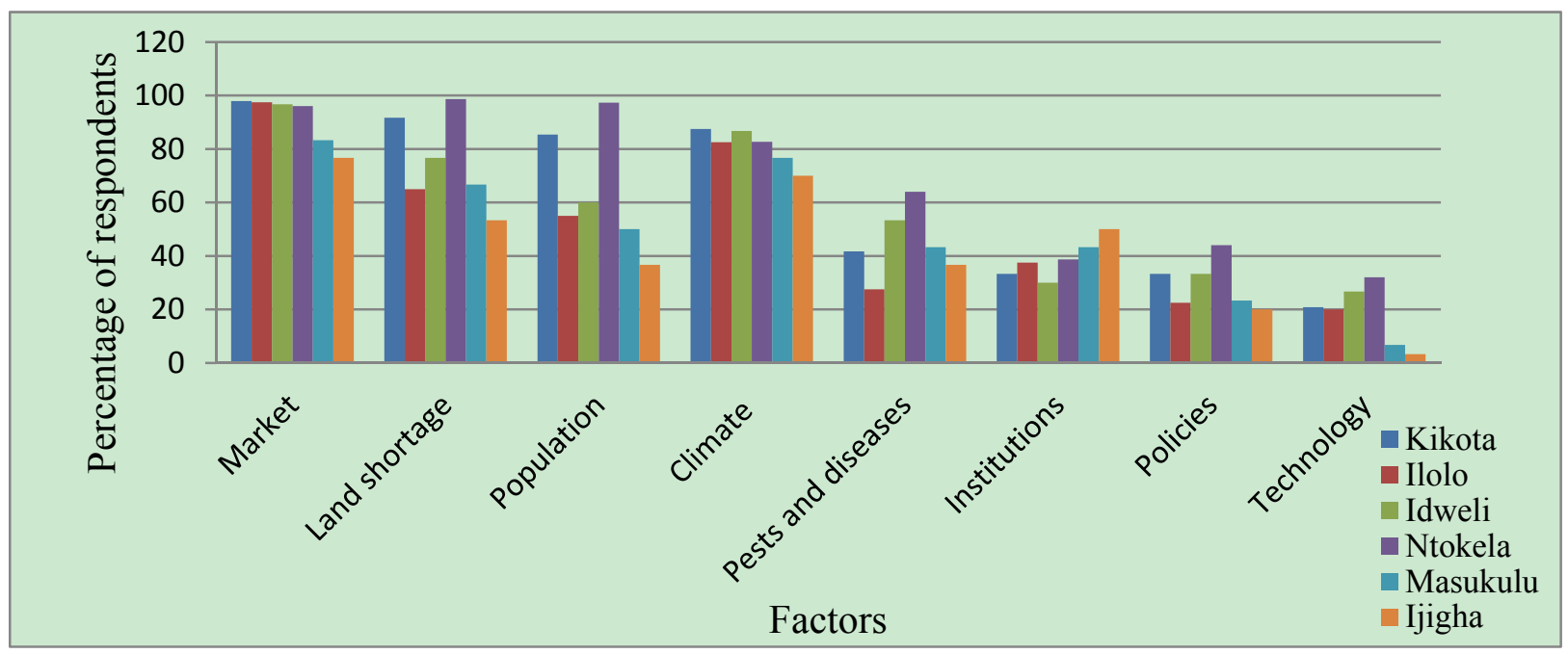

Figure 2. Factors influencing livelihoods diversification

\subsubsection{Markets}

Market has emerged as one of the major factors that influence livelihoods diversification in the study villages. In the study area, market had the highest response rate from respondents followed by land shortage. The responses from respondents varied across the villages, where Kikota and Ilolo had the highest responses (Figure 2). In this regard, the majority of households indicated that they have diversified from food crop production into cash crop production and trade due to high demand of those food crops. However, KIIs and FGDs revealed that increased participation in crop production for sale was due to readily available market which promoted farmers to engage more in the production of crops like banana, paddy, and round potatoes, for sale than for consumption. In view of this, the presence of good markets was contributed by good transport services, which led to easy access to market areas.

According to FGDs, results indicated that there had been a decline in the production of crops like coffee, tea, sweet potatoes, cassava, and yams in Kikota, Ilolo, Masukulu and Ijigha villages, due to the poor market for them. In addition, some households in Ntokela and Idweli villages have stopped cultivating crops like pyrethrum, 
wheat, finger millet and sorghum due to their poor market condition and are currently involved in the production of round potatoes, garlic, cabbages and tomatoes, which were of great demand.

More importantly, results on the relationship between the market and livelihoods diversification using a chi square test revealed that there was statistically significant association between market and livelihoods diversification into trade (13.349, $\mathrm{P}=0.000)$, renting land $(10.886, \mathrm{P}=0.001)$, cash crop production $(9.185, \mathrm{P}=$ $0.002)$, lumbering $(8.878, \mathrm{P}=0.003)$ and honey production $(8.633, \mathrm{P}=0.003)$. In light of this, market was observed to have a significant influence on several livelihoods activities like trade, cash crop production, renting land, honey production and lumbering. This implies that market was considered as an important factor influencing livelihoods diversification than other factors in the study area.

Empirical literature on various studies has similar observation on the role of markets on livelihoods diversification. Ponte (1998) in Morogoro and Songea observed that households responded to market opportunities by diversifying from slow-maturing crops into fast-maturing crops. Sokoni (2001) in Uporoto highland indicated that the production of peas, finger millet and sweet potatoes has declined and replaced by crops like round potatoes, onions, beans and cabbages, which have a ready market in urban centres. Similarly, Anderson (1996) highlighted that pyrethrum production in Tanzania declined because of falling world market prices that led to diversification into the production of round potatoes. Tilumanywa (2013) equally observed that the poor market for traditional cash crops like coffee, tea and pyrethrum discouraged farmers from continuing to depend on these crops as a source of income. According to Nkonya Pender, Kaizzi, Kato, Mugarura, Ssali and Muwonge (2008) in Uganda reported equally that households with better access to markets and infrastructure tended to diversify into various livelihoods activities.

\subsubsection{Land Shortages}

With respect to the issue of land, land shortage has emerged as one of the factors influencing livelihoods diversification in Rungwe district. As indicated in Figure 2, results show that there were variations across the villages but generally the majority of respondents $(80.2 \%)$ pointed out that shortage of land has prevented them from diversifying into land-related activities, particularly crop diversification. A small amount of land was considered not enough to make a satisfactory living from agriculture alone, which forced thems to be involved in non-farm activities for additional income. Some farming households $(66.4 \%)$ in the study villages own a limited size of land, which has restricted them from diversifying their livelihoods because they cannot afford to buy land.

Chi-square results on the relationship between land shortage and livelihoods diversification showed that the association between land shortage and diversification into trade was significant with the value of 12.738 at $\mathrm{P}=$ 0.000 and between land shortage and lumbering with the value of $8.120, \mathrm{P}=0.004$. Ellis and Allison (2004) argued that livelihoods diversification occurs in response to land scarcity. Demissie and Legesse (2013) also reported that access to livelihoods asset such as land found to determine the involvement in rural livelihoods diversification particularly, the land based activities.

In addition, Yenesew et al. (2015) and Bantider, Hurni and Zeleke (2011) reported from case studies in Ethiopia that a small amount of cultivated land was not enough for households to make a sufficient living, thus, a need to look for other activities. Further, Tiffen et al. (1994) showed that one of the options for farmers in response to land scarcity was to look for supplementary livelihoods activities within and outside agriculture to meet household need (Barrett 2001 and Ellis 2000).

\subsubsection{Population Pressure}

Population pressure was one of the factors influencing livelihoods diversification in the study area. Based on this aspect, the study results showed that population pressure is one of the factors influencing livelihoods diversification in the study villages where Ntokela village had the highest percentage than other villages (Figure 2). Due to increase in population, households were compelled to diversify into various activities to compensate for the limited gains obtained from agriculture. According to the national population census, in Rungwe District the population increased from 306,380 in 1988 to 307,270 people in 2002, and to 339,157 people in 2012 (URT, 1990; URT, 2005; URT, 2013) (Figure 3). 


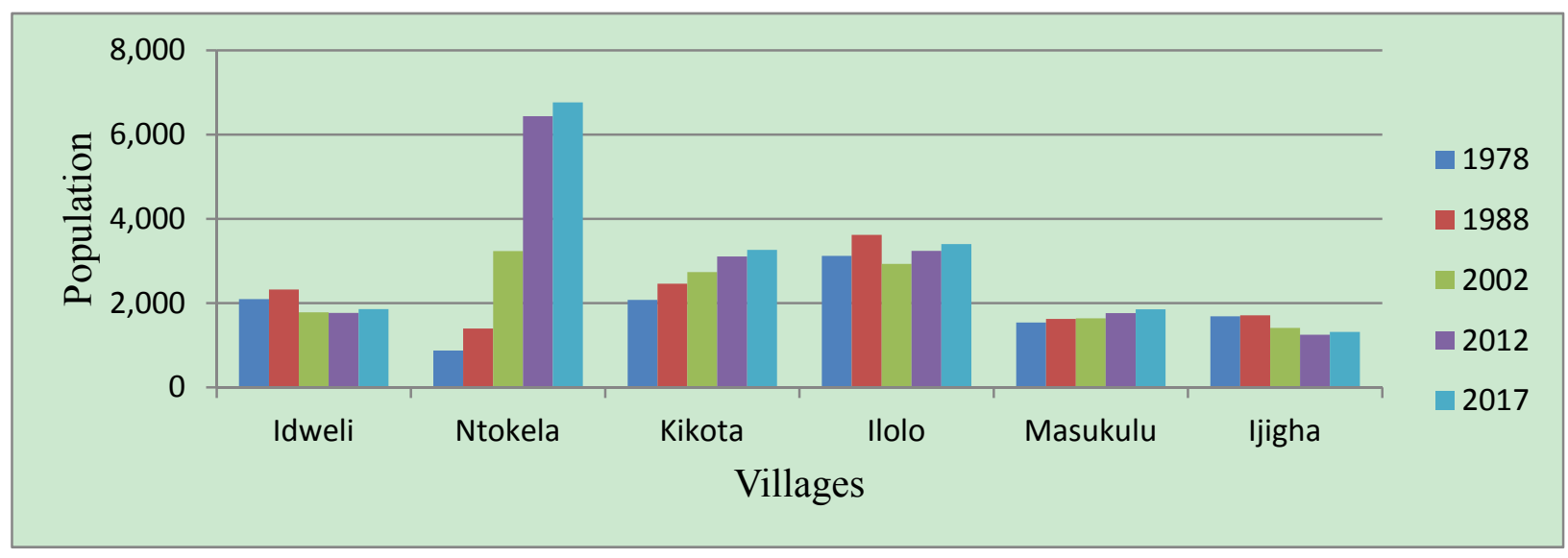

Figure 3. Population trend of the study villages

As indicated in Figure 3, the population of some of the study villages like Ntokela, Kikota and Masukulu has increased over time. For instance, based on population census reports of 1978, 1988, 2002 and 2012, in Ntokela, Kikota and Masukulu, the village population has increased over time but its impact varies because of population density and proximity to markets. Through a chi-square test, the association between population and livelihoods diversification into trade and lumbering was statistically significant with the value of $9.158, \mathrm{P}=0.002$ and $15.168 \mathrm{P}=0.000$, respectively.

According to KIIs, population pressure has led to livelihoods diversification due to the growing market demand for various goods such as bananas, round potatoes meat, milk and eggs. For instance, the increase in population promoted households to diversify into dairy farming and fast-maturing crops so as to meet the demand of the growing population in both rural and urban areas. In Ntokela village the population has been increasing over time due to in-migration from other wards and districts so as to be involved in activities related to production of round potatoes and trade, which was facilitated by commercialisation of the crop in the area. Kangalawe et al. (2008) in the Lake Victoria basin also revealed that population pressure results in diversification into various activities because agriculture cannot satisfy the available population. Likewise, Larsson (2001) pointed out that population growth forced people to diversify to meet the need of the growing population.

\subsubsection{Climate}

Regarding this aspect, climate has also been regarded as one of the factors which influenced livelihoods diversification in the study villages. Livelihoods diversification has been used by farming households as an adaptation mechanism for mitigating the impact of climate change and climate variability in the study villages. About $81.4 \%$ of respondents indicated that climate variability has encouraged livelihoods diversification in the area (Figure 2). For example, households have diversified from traditional crop varieties into improved crop varieties because the amount of rain that falls is insufficient and unreliable, which restricts the growing of particular crops. For instance, in all the study villages, majority of the household respondents $(92.1 \%)$ reported that insufficient amount of rain has encouraged them to diversify from traditional maize varieties into improved varieties which seem to mature earlier than the previously cultivated indigenous varieties, thus overcoming the problem of the and unreliable rains. In Rungwe District, some years and months has little rain such as in 2011 and 2013(Figure 4). 


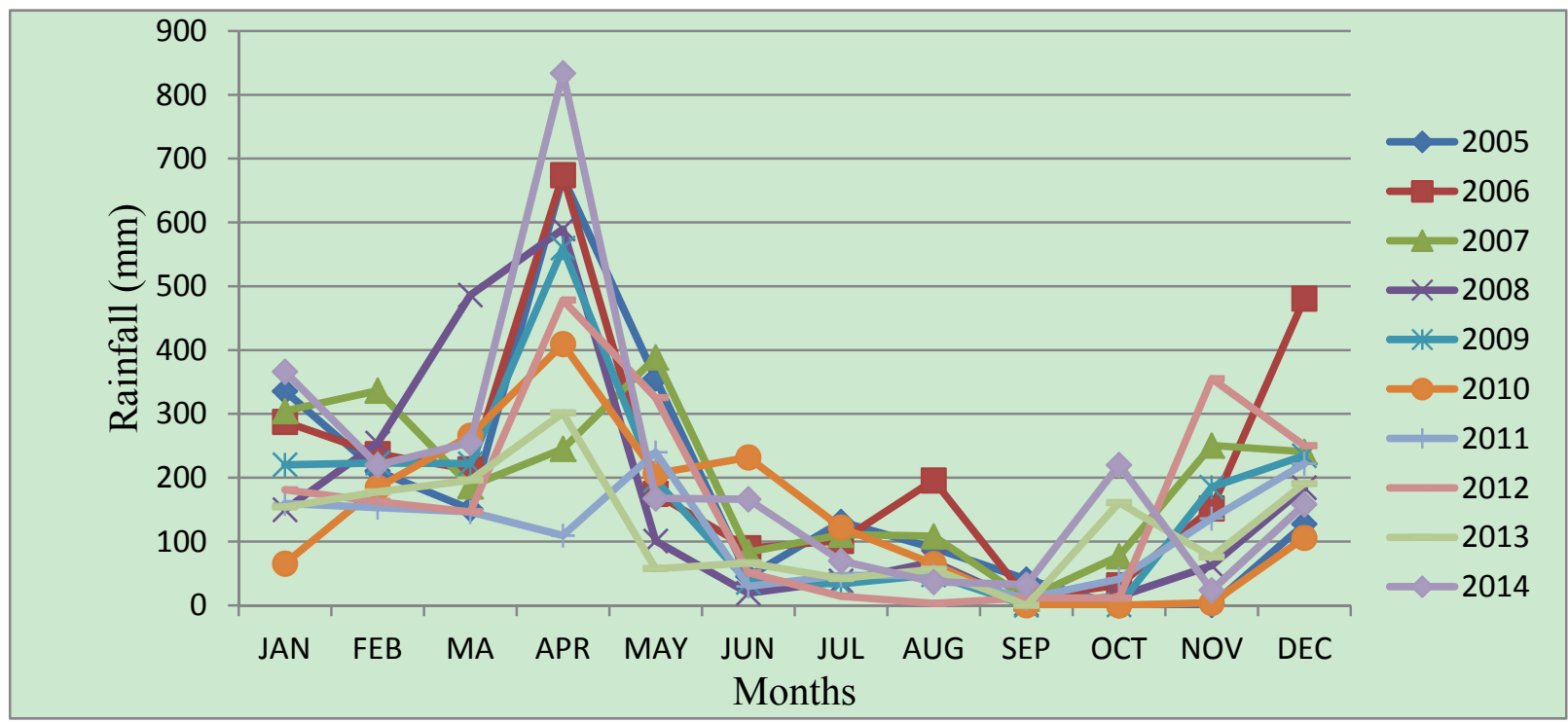

Figure 4. Climate data on annual rainfall (Mm) from 2005 to 2014

As indicated in Figure 4, there was a pick of rainfall on April and May this has promoted the season of growing beans in the area to remain unchanged over time while there has been a change in growing season for maize. From 2011 to 2014 the growing of maize has taken place on October instead of July/August because sufficient amount of rainfall for maize growing has occurred on October. Therefore, diversification into improved crop varieties was adopted as an adaptation mechanism because they mature earlier than the traditional ones. Key informant interviews reported that the inadequate and unreliable rainfall has forced farmers to be involved in other activities like trade, driving motorcycles and wage labour.

The observation about livelihoods diversification due to climate variability was also observed by Hussein and Nelson (1998) that a fundamental incentive to diversify from primary production was due to the unreliable rainy season and a long dry season. This was also reported by John et al. (2014) that in Karatu District, various households are involved in various livelihoods activities to supplement their income that have deteriorated due to a decline in agricultural production caused by periodic drought in the area. Also, these findings on drought are consistent with those of Kangalawe et al. (2008) that in Tarime District (Tanzania), Vihiga District (Kenya) and Wakiso district (Uganda) there have been a change in the composition of traditional food crops due to increased drought, which led to diversification into various activities instead of depending only on agriculture. Similarly, a study by Saha and Bahal (2014) revealed that in West Bengal, to cope with the uncertainties of the agricultural output caused by rainfall unreliability, households have involved in other livelihoods activities such as dairy farming, piggery, sheep rearing, and poultry as additional activities to generate fund on periodic basis. Similar findings was reported in Karatu district by John, Hambati and Armah (2014) that households have diversified into crops like pigeon peas, sorghum and sunflower as an adaptation mechanism for dealing with drought condition. In line with these findings a study by Demissie and Legesse (2013) revealed that farmers living in drought prone and risky areas like Fedis, Ethiopia tend to cultivate different types of crops to minimise the risk of crops failure that may result from drought condition in the area.

\subsubsection{Pests and Diseases}

Based on this aspect, the study results on pests and diseases indicated that households were forced to use certain types of crops or animal, which are less susceptible to disease and attack by pests. Some of the traditional varieties of banana have been affected by pests like banana weevils and nematodes as well as diseases like wilting and fungal diseases, thus a need to use improved varieties. For instance, in Kikota and Ilolo villages it was revealed through KIIs and FGDs that farmers have diversified from local types of bananas, known locally as kisukari, halale and mwamnyila, into improved varieties such as Phia, yangambi, Grandenaine, Williams, and Chinese Cavendish, which are less susceptible to pests and diseases. Also KIIs reported that the disease attack to pigs forced farmers to be involved in dairy cattle than keeping pigs, thus increasing the number of dairy farmers in the area. 


\subsubsection{Institutions}

This study considered institutions as among the factors that played an important part in promoting livelihoods diversification in the study villages. According to this aspect, the findings from this study indicated that institutions have also played an important role towards promoting livelihoods diversification in the study areas. Various institutions have encouraged rural households to diversify their livelihoods activities in the area (see Figure 2). Conversely, the Rungwe District Agricultural and Livestock officer indicated that livelihoods diversification in the district has been facilitated by various institutions, such as Heifer Project International (1996-2006), Tanzania Social Action Fund (TASAF), District Agricultural Development Plans (DADPS) (2006-2013), Africa Bridge (2010-2015) and East Africa Dairy Development Project (EADD II) (2014-2017). In principal, these institutions have been encouraging farmers in the district to diversify into trade, livestock keeping, cash crop production and tree planting, as well as providing some tree seedlings freely to those in need while educating them on the importance of livelihoods diversification to alleviate poverty. Also, the Uyole Agricultural Institute has also been promoting diversification into improved livestock breeds and improved seeds in the district.

This was equally supported by the Chi-square test which showed that the influence of institutions on livelihoods diversification into trade was found to be significant at the value of $8.606, \mathrm{P}=0.003$ and diversification into cash crop production at $10.719, \mathrm{P}=0.001$. Also, FGDs and KIIs, reported that various companies like the Rungwe Avocado Company, Lima Kwanza Company, Techno Save Company (TSC), WATCO, MeTL and the World Conservation Society (WCS) had motivated farmers to diversify their livelihoods and apply proper LMPs for high productivity. Techno Save Company (TSC) has encouraged rural households, especially in Masukulu and Ijigha villages, to diversify into cocoa production and tree planting and educated them on appropriate ways of cocoa production so as to fetch a high price in the market while improving their land productivity. The company has provided extension services to farmers and educated them on environmental conservation techniques.

\subsubsection{Livelihoods Assets}

With available livelihoods assets such as human capital, physical capital, financial capital, social capital and natural capital (Carney, 1998), households may decide on the type of activity to engage in. Accessibility to livelihoods assets have impact on livelihoods diversification due to the fact that farming households normally diversify their activities based on their access to different types of assets (Reardon, 1997). Indicators of human capital include age, education level and sex (Yizengaw, Okoyo and Beyene, 2014). In Rungwe, district human capital was observed to be poor particularly, in terms of secondary and post-secondary levels whereas the majority of households had received a primary education and only few household heads attained a secondary or post-secondary level. Low education level may limit households from gaining employment in the government or the private sector. The majority of households have owned only the simple tools like hand hoes, axes and machetes. Natural capital: In the study villages many farming households depend on agriculture for their livelihoods, and so land is their main resource for producing crops that can influence diversification into various livelihoods activities. Small land size cannot meet household requirements and so they need to diversify into other activities. Good transport and communication facilities are very important for diversifying livelihoods in rural areas. For instance, in Ntokela, Idweli, Kikota and Ilolo villages good transport facilities have enabled households to have access to markets unlike Masukuklu and Ijigha villages, which have poor transport services. Also social capital was observed to be important in the study villages. Many respondents $(73 \%)$ indicated that they are members of different associations for social and economic support.

\section{Conclusions and Recommendations for Policy Implications}

\subsection{Conclusions}

This paper investigated the factors that have influenced livelihoods diversification in Rungwe district and assessed the livelihoods activities in the study area.Based on the study results, this paper argues that while there was diversity of livelihoods activities, agriculture has remained the main occupation of many households in the district. The results indicate that although most of the households were much more involved in diverse livelihoods activities, yet, their income has not increased significantly because the activities they performed were at low levels due to inadequate capital to run big businesses. Similarly, poor transport facilities and land shortages were accorded high priority as among the critical problems which were facing households. Consequently, such factors prevented them from effective involvement in livelihoods diversification, and thus they became more vulnerable to poverty conditions.

According to the findings of this paper, market was also observed as one of the most significant factor in influencing livelihoods diversification than other factors. This was much more evident with respect to the 
chi-square test which indicated that market has a significant association with several livelihoods activities like trade, cash crop production, renting land, and lumbering while other factors had a significant association with only one or two livelihoods activities. Generally, this paper puts more emphasis on the need to strike a balance between rural areas where the poor majority live and the urban areas. This has been so because livelihoods diversification was found to have significant impacts in urban areas than in rural areas. For example, transport services as one of the factors which influenced livelihoods diversifications had significant impact in urban areas due to improved services than in rural areas where such services were not adequately improved. As a consequence of this, this created a situation of imbalanced opportunities for livelihoods diversifications due to poorly linked services such as transport and markets.

On that basis, since this paper examined the drivers of livelihoods diversification, it has come up with both theoretical and practical contributions to the livelihood framework in the context of capability approach. The relevance of this theory can be viewed in relation to its contribution to engendering a significant shift in development thinking towards greater focus on poverty reduction in improving household welfare. The paradigm has been regarded useful to priorities people as the focal subjects of any policy planning and design, thus creating better scope for poverty reduction strategies. With the use of the capability approach in the context of sustainable livelihoods framework, the approach have put greater emphasize on determining such things as household income and food security. Therefore, since this study has examined the drivers of livelihoods diversification towards enhancing peoples' livelihoods among smallholder farmers in the agricultural sector, the use of sustainable livelihood framework has been useful in providing a better understanding of how factors influencing livelihoods diversification might affect livelihoods of smallholder farmers. More importantly, the framework would also help to determine how livelihoods are carved out through livelihoods strategies and/or coping mechanisms which are reflected in livelihoods outcomes.

\subsection{Recommendations}

Based on the study results, the following recommendations can be drawn from this paper for policy options in response to the challenges observed in this paper.

The study recommends that the government should improve transport services in rural areas in order to provide equal opportunities for livelihoods diversification by rural population. This is in response to the fact that improved transport services were found to be important not only for promoting livelihoods diversification in rural areas but also for encouraging interdependence between livelihoods in rural and those of urban areas.

Since non-farm activities were found to have significant influence on households' income and land productivity, this paper recommends that the government should encourage the practice on non-farm activities to adequately reduce the direct dependency on land while providing access to capital for land management. For instance, the household's involvement in tree nurseries and tree planting improved both the household income and land productivity.

Although availability of market for commodities was another important factor that significantly influenced livelihoods diversification in the study area, yet such markets were not improved. On that basis, this paper recommends that the government should improve the market conditions essential for enhancing livelihoods diversification among farming households. To effectively undertake this, attention should be given to improving rural markets for agricultural crops by offering good prices. This in turn will encourage rural households to invest in crop diversification to maximize profit while promoting livelihoods. An improved market can promote diversification into various livelihoods activities for rural households.

Since agriculture has remained the main economic activity in the area, this paper recommends that the government should provide subsidies and improve farmers' access to inputs like fertilisers, herbicides and insecticides to help them transform their agricultural activities and obtain high-yielding seeds for improved livelihoods.

This paper also calls for the need of various stakeholders to implement reforms which support for the creation of a policy that would increase people's access to land in order to enhance their opportunities for livelihoods diversification particularly the land related activities. The increased access to land has greater possibilities to promote diversification because land was one of the main natural capitals for rural households.

\section{Acknowledgements}

The authors of this manuscript would like to thank all academic and non-academic staff at the Institute of Resource Assessment, University of Dar es Salam for their constructive comments, encouragement and cooperation. Special thanks are also directed to the management of Mwalimu Nyerere Memorial Academy for 
their support and advice during the study period. My heartfelt thanks are also extended to Rungwe District officers for providing relevant information for the study. My sincere gratitude is equally extended to Kiwira, Isongole and Masukulu Ward Executive Officers as well as Village Executive Officers and farmers at Kikota, Ilolo, Idweli, Ntokela, Masukulu and Ijigha villages for their support and cooperation during field work.

\section{References}

Anderson, J. (1996). Potato Cultivation in the Uporoto Mountains, Tanzania: An Analysis of the Social Nature of Agro-technological Change. African Affairs, 95, 85-106. Retrieved from https://www.researchgate.net

Ashley, C., Start, D., \& Slater, R. (2003). Livelihood Diversity and Diversification. Understanding Livelihoods in Rural India: Diversity, Change and Exclusion. Livelihood Guidance Policy Sheet 2.3. Overseas Development Institute (ODI), London.

Assan, J. K. (2014). Livelihood Diversification and Sustainability of Rural Non-Farm Enterprises in Ghana. Journal of Management and Sustainability, 4(4). Retrieved from https://www.researchgate.net

Bantider, A., Hurni, H., \& Zeleke, G. (2011). Responses of Rural Households to the Impacts of Population and Land-use Changes along the Eastern Escarpment of Wello, Ethiopia. Norwegian Journal of Geography, 65(1), 42-53. https://doi.org/10.1080/00291951.2010.549954

Barrett, C. B., Reardon, T., \& Webb, P. (2001). Non-farm Income Diversification and Household Livelihood Strategies in Rural Africa: Concepts, Dynamics and Policy Implications. Food Policy, 26, 315-331. https://doi.org/10.1016/S0306-9192(01)00014-8

Bryceson, D. (2000). Rural Africa at the Crossroads: Livelihood Practices and Policies. ODI Natural Resource Perspectives No.52. Retrived from https://www.odi.org/sites/odi.org

Carney, D. (1998). Sustainable Rural Livelihoods: What Contribution Can We Make. Department for International Development (DFID), London.

Davies, S. (1996). Adaptable Livelihoods: Coping with Food Insecurity in the Malian Sahel. Macmillan Press, London.

Demissie, A., \& Legesse, B. (2013). Determinants of Income Diversification among Rural Households: The case of Smallholder Farmers in Fedis District, Eastern Hararghe Zone, Ethiopia. Journal of Development and Agricultural Economics, 5(3),120-128.

Dercon, S., \& Krishnan, P. (1996). Income Portfolios In Rural Ethiopia and Tanzania: Choices and Constraints. Journal of Development Studies, 32(6), 850-875. https://doi.org/10.1080/00220389608422443

Devereux, S., Teshome, A., \& Sabates-Wheeler, R. (2005). Too Much Inequality or Too Little? Inequality and Stagnation in Ethiopian Agriculture. IDS Bulletin, 36(2), 121-126. https://doi.org/10.1111/j.1759-5436.2005.tb00208

Ellis, F. (2000). Rural Livelihoods and Diversity in Developing Countries. Oxford University Press.

Ellis, F., \& Allison, E. (2004). Livelihood Diversification and Natural Resource Access. Overseas Development Group, University of Anglia, LSP Working. http://doi.org/10.1016/j.worlddev.2006.02.006

Geist, H., \& Lambin, E. (2002). Proximate Causes and Underlying Driving Forces of Tropical Deforestation. Bioscience, 52(2), 143-150. Retrieved from www.academic.oup.com/bioscience/article52/2/143/341135

Hussein, K., \& Nelson, J. (1998). Sustainable Livelihoods and Livelihood Diversification. IDS Working Papers No. 69. Falmer, Brighton. Retrieved from https://www.ids.ac.uk/files/Wp69.pdf

Iiyama, M., Kariuki, P., Kristjanson, P., Kaitibie, S., \& Maitima, J. (2008). Livelihoods Diversification Strategies, Incomes and Soil Management Strategies: A Case Study from Kerio Valley, Kenya. Journal of International Developmen, 20, 380-397. https://doi.org/10.1002/jid.1419

John, L. R., Hambati, H., \& Armah, F. A. (2014). An Intensity Analysis of Land-Use and Land-Cover Change in Karatu District, Tanzania:Community Perceptions and Coping Strategies. African Geographical Review, 33(2), 150-173. https://doi.org/10.1080/19376812.2013.838660

Kangalawe, R. Y. M., Liwenga, E. T., Kabumbuli, R., \& Walingo, M. K. (2008). Livelihood Diversification and Implications On Poverty and Environment in the Lake Victoria Basin. African Journal of Environmental Science and Technology, 2(10), 272-281.

Katega, I., \& Lifuliro, C. (2014). Rural Non-Farm Activities and Poverty Alleviation in Tanzania: A Case Study of Two Villages in Chamwino and Bahi Districts of Dodoma Region. Retrieved from 
www.repoa.or.tz/documents/REPOA RR14 7.pdf

Kwai, B., \& Hilson, G. (2010). Livelihood Diversification and the Expansion of Artisanal Mining in Rural Tanzania: Drivers and Policy Implications. Outlook on Agriculture, 39(2), 141-147. https://doi.org/10.5367/000000010791745358

Larsson, R. (2001). Between Crisis and Opportunity: Livelihoods, Diversification and Inequality among the Meru of Tanzania. Unpublished material of the Lund University, Sweden.

Lesslie, R. (2004). Land use and Land Management Practices: Concepts, Terms and Classification, Principle. Retrived from https://www.researchgate.net

Little, P. D., Smith, K., Cellarius, B. A., Coppock, D. L., \& Barrett, C. B. (2002). Avoiding Disaster: Diversification and Risk Management among East African Herders. Development and Change, 32, 401-433. https://doi.org/10.1111/1467-7660.00211

Loison, S. A., \& Loison, S. A. (2016). Rural Livelihood Diversification in Sub-Saharan Africa: A literature review. Journal of Development Studies, 51, 1125-1138.

Low, P. S. (2005). Climate Change and Africa. Cambridge university, New York.

Majule, A. (2010). The impact of land management Practices on Soil Quality and Implications on Smallholder Productivity in Southern Highland Tanzania. Environmental Economics, 1, 59-67. Retrieved from https://businessperspectives.org/images/pdf/applications

McCabe, J. T. (2003). Sustainability and Livelihood Diversification among the Maasai of Northern Tanzania. Human Organisation, 62, 100-111. https://doi.org/10.17730/humo.62.2.4rwrtln3xptg29b8

Mwakaje, A. G. (2008). Dairy Farming and Biogas Use in Rungwe District, Southwest Tanzania: A study of opportunities and constraints. Renewable and Sustainable Energy Review, 12(8).

Mwamfupe, D. (1998). De-agrarianisation and Rural Employment Network. Changing Village land, Labour and Livelihoods: Rungwe and Kyela District, Tanzania. Leiden and Dar es Salaam: African-studiecentrum, Leiden and Institute of Resource Assessment, University of Dar es Salaam. Working paper vol. 29.

Newsham, A., \& Thomas, D. (2009). Agricultural adaptation, local knowledge and livelihoods diversification in north-Central Namibia. Tyndall Working Paper 140. Retrieved from https://tyndall.ac.uk/sites/default/files/publications/twp140.pdf

Nkonya, E., Pender, J., Jagger, P., Sserunkuuma, D., Kaizzi, C., \& Ssaliu, H. (2004). Strategies for Sustainable Land Management and Poverty Reduction in Uganda. Research report 133. Retrieved from www.ifpri.org

Nkonya, E., Pender, J., Kaizzi, C., Kato, E.,Mugarura, S., Ssali, H., \& Muwonge, J. (2008). Linkages between Land Management, Land Degradation and Poverty in Sub-Saharan Africa, The Case of Uganda. International Food Policy Research Institute. Retrieved from www.ifpri.org

Nussbaum, M. (2000). Women and Human Development: The Capabilities Approach. Cambridge University Press, Cambridge.

Pender, J., Jagger, P., Nkonya, E., \& Sserunkuuma, D. (2004). Development Pathways and Land Management in Uganda. World Development, 32(5), 762-792. https://doi.org/10.1016/j.worlddev.2003.11.003

Ponte, S. (2002). Farmers and Markets in Tanzania: How Policy Reforms Affect Rural Livelihoods in Africa. Mkuk ina Nyota Publishers, Dar ea Salaam.

Reardon, T. (1997). Using evidence of household income diversification to inform study of the rural nonfarm labor market in Africa. World Development, 25, 735-747. https://doi.org/10.1016/S0305-750X(96)00137-4

Robeyns, I. (2003). Sens' Capability Approach and Gender Inequality: Selecting Relevant Capabilities. Feminist Economics, 9(2-30), 61-92. https://doi.org/10.1.1.335.803\&rep

Saha, B., \& Bahal, R. (2014). Livelihood Diversification Pattern among the Farmers of West Bengal. Economic Affairs, 59(3), 321-334. https://doi.org/10.5958/0976-4666.2014.00001.1

Sen, A. (2005). Human Rights and Capabilities. Journal of Human Development, 6(2). Retrieved from https://pdfs.semanticscholar.org/b99a/d40597c7f2396eeb7128b979e9bd97b7562d.pdf

Sokoni, C. (2001). The Influence of Agricultural Marketing Reforms on Highland Farming Systems in Tanzania, The case of The Uporoto Highland, Mbeya Region. A PhD Thesis of the University of Dar es salaam.

Sserunkuuma, D., Pender, J., \& Nkonya, E. (2001). Land Management in Uganda: Characterization of Problems 
and Hypothesis Causes and Strategies for Improvement. International Food Policy Research Institute (IFPRI). Retrived from https://www.researchgate.net/publication/237527114

Start, D., \& Crag, J. (2004). Livelihood Options? The Political Economy of Access, Opportunity and Diversification. Working $233 . \quad$ Paper Retrieved from https://www.odi.org/sites/odi.org.uk/files/odi-assets/publications

Tefera, L., Perret, S., \& Kirsten, J. F. (2004). Diversity in Livelihoods and Farmers' Strategies in the Hararghe Highlands, Eastern Ethiopia. International Journal of Agricultural Sustainablility, https://doi.org/10.1080/14735903.2004.9684573

Tiffen, M., Mortimore, M., \& Gichuki, F. (1994). More People, Less Erosion: Environmental Recovery in Kenya. London, John Wiley \& Sons.

Tilumanywa, V. T. (2013). Land Use and Livelihood Changes in the Mount Rungwe Ecosystem, Tanzania. A PhD Thesis of the Stellenbosch University.

Urassa, J. K. (2010). Rural Household Livelihoods, Crop Production and Wellbeing after a Period of Trade Reforms: A Case Study of Rukwa, Tanzania. A PhD Thesis of the University of Sussex, Brighton.

URT (The United Republic of Tanzania). (1990). 1988 Population Census: Regional Profile, Mbeya. Bureau of Statistics, President's Office, Planning Commission, Dar es Salaam.

URT (The United Republic of Tanzania). (2005). 2002 Population and Housing Census: Village and Street Statistics: Mbeya Region. Volume VII. National Bureau of Statistics, President's Office Planning and Privatization, Dar es Salaam.

URT. (2013). 2012 Population and Housing Census: Population Distribution by Administrstive Areas. National Bureau of Statistics, Dar es Salaam, and the Office of of the Chief Government Statistician, Zanzibar.

Woodfine, A. (2009). Using Sustainable Land Management Practices to Adapt to and Mitigate Climate Change in Sub Saharan Africa. Resource guide Version 10. Retrived from http://www.ipcinfo.org/fileadmin/user_upload/terrafrica/docs

Yenesew, S. Y., Okoyo, E. N., \& Beyene, F. (2015). Determinants of Livelihoods Diversification Strategies: The case of Smallholder Rural Farm Households in Debre Elias Woreda, East Gojjam Zone, Ethiopia. African journal of Agricultural Research. Retrieved from https://academicjournals.org/journal

Yizengaw, Y. S., Okoyo, E. N., \& Beyene, F. B. (2014). Determinants of Livelihood Diversification Strategies: The Case of Smallholder Rural Farm Households in Debre Elias Woreda, East Gojjam Zone, Ethiopia. African Journal of Agricultural Research, 10(19).

\section{Copyrights}

Copyright for this article is retained by the author(s), with first publication rights granted to the journal.

This is an open-access article distributed under the terms and conditions of the Creative Commons Attribution license (http://creativecommons.org/licenses/by/4.0/). 